\title{
Description of Age-0 Round Goby, Neogobius melanostomus Pallas (Gobiidae), and Ecotone Utilisation in St. Clair Lowland Waters, Ontario
}

\author{
JoHn K. LesLiE and Charles A. Timmins
}

Great Lakes Laboratory for Fisheries and Aquatic Sciences, Department of Fisheries and Oceans, 867 Lakeshore Road, Burlington, Ontario L7R 4A6 Canada

Leslie, John K., and Charles A. Timmins. 2004. Description of age-0 Round Goby, Neogobius melanostomus Pallas (Gobiidae), and ecotone utilisation in St. Clair lowland waters, Ontario. Canadian Field-Naturalist 118(3): 318-325.

Early developmental stages and ecotone utilisation of the non-indigenous Round Goby, Neogobius melanostomus (Pallas, 1811), are described and illustrated. Fish $(5-40 \mathrm{~mm})$ were collected in coarse gravel, rocks and debris in the St. Clair River/Lake system, Ontario, in 1994-2000. The Round Goby hatches at about $5 \mathrm{~mm}$ with black eyes, flexed urostyle, and developed fins and digestive system. Distinguishing characters include large head, dorsolateral eyes, large fan-shaped pectoral fins, two dorsal fins, fused thoracic pelvic fins and a distinct black spot on the posterior of the spinous dorsal fin. Modal counts for preanal, postanal, and total myomeres were 12,19 , and 31, respectively.

Key Words: Round Goby, Neogobius melanostomus, St. Clair aquatic ecosystem, age-0, morphometry, habitat, Ontario.

Gobiidae, the largest family of marine fishes, has been found in fresh waters of all continents (Nelson 1984) except Antarctica. None of 68 species endemic to North America is native to the Great Lakes, where two introduced species, the Round Goby, Neogobius melanostomus (Pallas, 1811) and the Tubenose Goby, Proterorhinus marmoratus (Pallas, 1811), recently became established. These fishes originate in the PontoCaspian region (Caspian, Azov and Black seas and Sea of Marmara). International ships' ballast was assumed the most probable means by which Round Goby eggs and/or postembryonic stages were transferred from the Black Sea to the Great Lakes (Crossman et al. 1992; Jude et al. 1992). Since its arrival in the midlate 1980s the relatively innocuous Tubenose Goby has not proliferated beyond the St. Clair-western Lake Erie ecosystem (Leslie et al. 2002). In contrast, the aggressive, eurytopic Round Goby has diffused extensively and is now one of the most abundant fish in the Great Lakes basin. Apparently, repetitive spawning and habitat requirements of this fish conflict with our native species (Dubs and Corkum 1996), some of which they may supplant.

The Round Goby is a guarding cavity spawner with a life span of 4-5 years (Miller 1986). Spawning season is typically from spring to late summer. Rocks, gravel, solid objects with crevices and submersed plants are used for egg deposition (Miller 1986; Skóra 1997*). Whereas literature abounds on the ecology of adults, information on postembryonic fish is rare. Eggs and early developmental stages in southern Russia and Ukraine have been described by Moskal'kova (1967), Kalinina (1976), and Koblickaja (1981). This report presents information on aspects of taxonomy and ecotone utilisation of age- 0 Round Gobies in the Great
Lakes and considers possible effects the species may have on the aquatic community in general and native fishes in particular.

\section{Study Area}

Eggs and age-0 fish were collected at numerous locations at the shore of the St. Clair River, Ontario, various sites along the southeastern shore of Lake St. Clair, and in Duck Creek $\left(42^{\circ} 17^{\prime} \mathrm{N}, 82^{\circ} 35^{\prime} \mathrm{W}\right)$, a low gradient stream tributary to Lake St. Clair (Figure 1). Duck Creek is a disturbed system draining a small area in one of the most highly cultivated agricultural regions in Canada. It is approximately $9 \mathrm{~km}$ long and 10-15 m wide near its mouth, where most specimens were collected. Mid-stream depth ranges from 1.2 to $1.6 \mathrm{~m}$. In April to November 1995, mean conductivity was $487 \mu \mathrm{S} / \mathrm{cm}$ and Secchi disc depth $0.3 \pm 0.1 \mathrm{~m}$, reflecting high suspended particulate load due to runoff from cropland. Substrate at the sampling site is mainly alluvium, with clay and scattered debris of human origin at the base of 1-4 m high stream banks. However, age-0 Round Gobies were found only on a small gravelled area at the base of a railway bridge.

Duck Creek has a large diverse, albeit transient, fish assemblage of at least 41 species (Leslie and Timmins 1998) dominated by Gizzard Shad Dorosoma cepedianum, Bluntnose Minnow Pimephales notatus, Spottail Shiner Notropis hudsonius, and Bluegill Lepomis macrochirus. Submersed plants near the collection site include Pondweed Potamogeton spp., Eelgrass Vallisneria americana, Canada Waterweed Elodea canadensis, Eurasian Milfoil Myriophyllum spicatum, and Curly Pondweed Potamogeton crispus. Arrowhead Sagittaria sp., Sedge Carex sp., Cattail Typha spp., and Bulrush Scirpus spp. were abundant emergent species. 


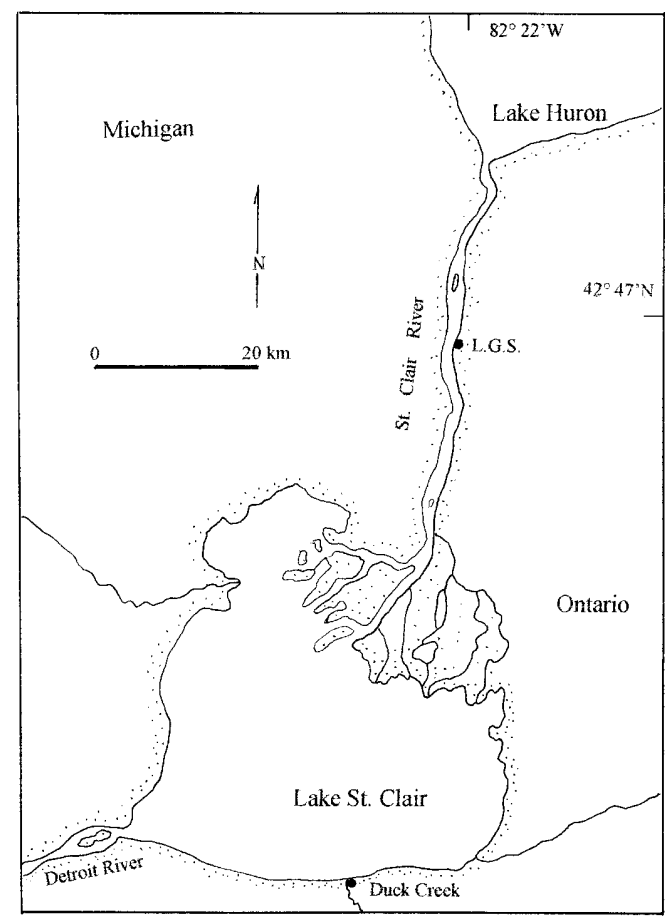

FIGURE 1. Main sites where age-0 Neogobius melanostomus were collected in the St. Clair River-Lake ecosystem in 1994-2000: LGS (Lambton Generating Station) and Duck Creek.

Round Goby eggs and age- $(0$ developmental stages as well as numerous co-occurring fishes were found at various locations at the shore of the St. Clair River, mainly in dilute condenser cooling water discharge of Lambton Generating Station (LGS) $\left(42^{\circ} 47^{\prime} \mathrm{N}\right.$, $\left.82^{\circ} 22^{\prime} \mathrm{W}\right)$. Random fish collections took place at LGS (Figure 1) each year between April and November 1994-2000 over a shoreline stabilised with debris, limestone boulders and rocks $0.3-1.0 \mathrm{~m}$ in longest dimension. This formation extends $4 \mathrm{~m}$ from shore on a natural substrate of sand. Most common fish species collected with age-0 Round Gobies in the St. Clair River include age-0 White Sucker Catostomus commersoni, Alewife Alosa pseudoharengus, Brook Silverside Labidesthes sicculus, Rainbow Darter Etheostoma caeruleum, Iowa Darter Etheostoma exile, Johnny Darter Etheostoma nigrum, Spottail Shiner, and Emerald Shiner Notropis atherinoides. Of these species, guarding speleophils Rainbow Darter, Iowa Darter, and Johnny Darter utilise common ecotones and probably compete with gobies for food and shelter.

\section{Methods}

A bulging larval fish beach seine ( $4 \mathrm{~m}$ long, $1 \mathrm{~m}$ wide, mesh $0.4 \mathrm{~mm}$ ) was necessary for capture of recently hatched gobies, which only emerged from protective crevices when the bottom of the seine dis- turbed the substrate. Two flat seines, $3 \mathrm{~m}$ long, $1 \mathrm{~m}$ wide ( $3 \mathrm{~mm}$ mesh), and $6 \mathrm{~m}$ long, $1 \mathrm{~m}$ wide $(6 \mathrm{~mm}$ mesh) were used to sample young and adult gobies and co-occurring species. All seine hauls took place repeatedly in contact with gravel at the base of a railway bridge over Duck Creek.

In the St. Clair River, clusters of eggs attached to rocks or human artefacts such as discarded sewer pipe were preserved intact with 5-10\% formalin and enumerated in the laboratory. Water temperature, specific conductivity, water transparency, substrate characteristics, and co-occurring fishes were recorded at all sampling locations except four that were devoid of cover and fishes.

Fish were preserved in a $12: 1$ solution of $80 \%$ ethanol and glycerin, respectively, and stored at room temperature $\left(22-25^{\circ} \mathrm{C}\right)$. A dissecting microscope equipped with an ocular micrometer was used for measurement and illustration of fish. Measurements $<5 \mathrm{~mm}$ were accurate to $\pm 0.1 \mathrm{~mm}$, and larger characters to $\pm 0.2 \mathrm{~mm}$. Several specimens were cleared to determine vertebra number. Fish used in this study are stored at the Royal Ontario Museum, Toronto, Ontario.

In general, terms used to describe fishes follow Trautman (1981). Base length of median fins is defined as the distance from the anterior margin of the first spine or soft ray to the posterior margin at the base of the last spine or ray. Snout length is the distance from the anterior margin of the premaxillary to the anterior margin of the eye. Interorbital width is the least distance between orbits. Body depth factor (BDF) and caudal depth factor (CDF) indicate general body form and swimming ability (Webb and Weihs 1986). Body depth factor is defined as mean TL/mean body depth, whereas $\mathrm{CDF}=$ mean caudal peduncle depth/ mean body depth. A high BDF and CDF denotes an elongate species whose depth is more or less the same along its length; e.g., clupeid or osmerid. Low values are found in centrarchids, where manoeuvrability is enhanced by a deep body and large pectoral fins. Fish volume, determined in each size class $=$ mean total length $\times(\text { mean body depth })^{2}$.

\section{Results}

\section{Reproductive and nursery habitat}

Environmental conditions for fish reproduction and rearing differed in Duck Creek and the St. Clair River according to water quality and physical characteristics. On most dates, water temperature at the shore of the river was about $3^{\circ} \mathrm{C}$ lower and suspended particulate load always lower, than in Duck Creek. Whether collected at $4^{\circ}$ or $30^{\circ} \mathrm{C}$, Round Gobies were recorded in the same habitat from April to November. However, their occurrence was contingent on availability of cover. For example, gobies were not found at LGS in May 1999 when low water level completely exposed rock and rubble habitat. Recently hatched fish were rarely found along featureless, sandy shores, where 

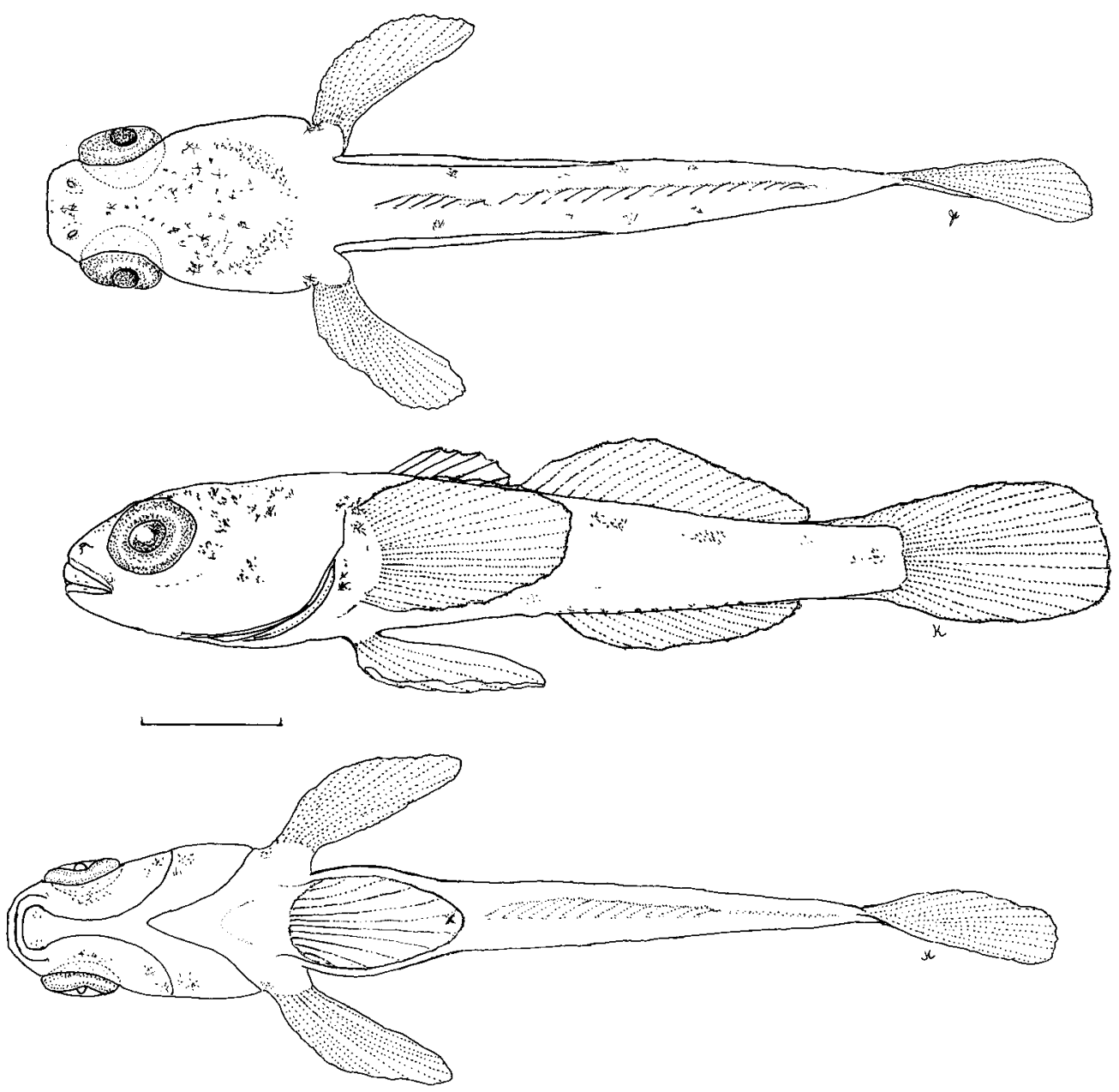

FIGURE 2. Neogobius melanostomus at $7.5 \mathrm{~mm}$; upper: dorsal, middle: lateral, lower: ventral view. Length bar $=1 \mathrm{~mm}$.

juvenile and adult gobies were occasionally caught. Small boat launches with corrugated concrete ramps were consistent sources of larger $(>30 \mathrm{~mm})$ specimens of age- 0 gobies.

Presence of small age-0 fish in late spring and early autumn indicates a possible prolonged spawning period in Duck Creek, accommodated by water temperature $>10^{\circ} \mathrm{C}$ from early May to mid-October. Earliest evidence of recently hatched fish (5-13 mm TL) on 1 June 1995 suggests spawning takes place in April or May. However, in early May 1998, ten gobies (22-28 $\mathrm{mm}$ ) were caught near LGS at $10^{\circ} \mathrm{C}$ above ambient $\left(4^{\circ} \mathrm{C}\right)$. These fish may have hatched in late winter in dilute heated power plant effluent. Since small gobies (14-23 mm) were found each year in September, spawning at LGS may extend to late summer.
In Duck Creek, Round Gobies endure continuous turbid water, enriched conditions, occasional dense blooms of blue-green algae (Anabeana sp; Cyanophyta) and temperature at least $30^{\circ} \mathrm{C}$. According to size in autumn, gobies attain a mean length of about 33$39 \mathrm{~mm}$ at the end of first year growth. For example, in Duck Creek fish were $32.8 \mathrm{~mm}$ (28-36 mm) in early October 1995, whereas at LGS, they were $37.6 \mathrm{~mm}$ (range 31-49 mm) in November 1994 and $39.4 \mathrm{~mm}$ (30-45 mm) in November 1995.

\section{Reproduction}

In mid-July 1999, numerous clusters of eggs were found attached to the underside of rocks at a depth of $0.3 \mathrm{~m}$ in Duck Creek. A sample $(\mathrm{N}=121)$ of eggs in a cluster of roughly 200 on a rectangular patch of about $30 \mathrm{~cm}^{2}$ averaged $3.0 \mathrm{~mm}$ long and $1.8 \mathrm{~mm}$ wide with 


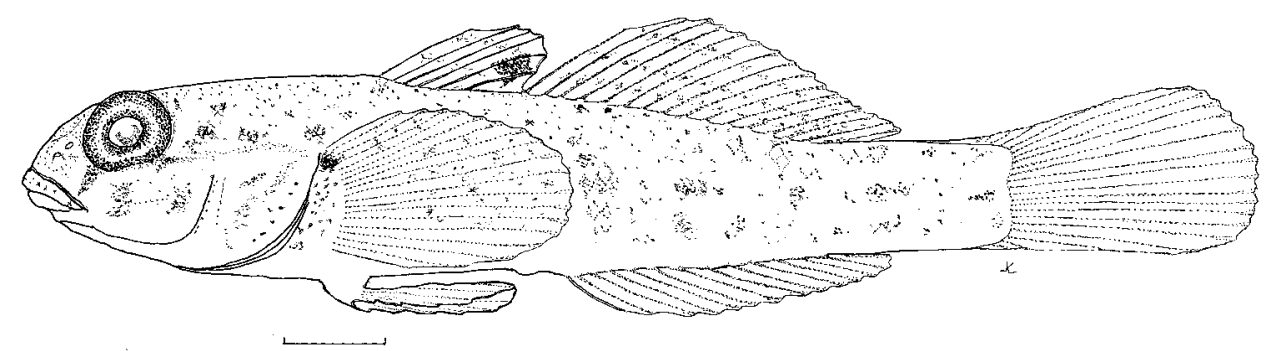

FIGURE 3. Neogobius melanostomus at $25 \mathrm{~mm}$. Length bar $=2 \mathrm{~mm}$.

respective modal values of $3.1 \mathrm{~mm}$ and $1.8 \mathrm{~mm}$ (range: 2.6-3.3 $\mathrm{mm}$ and 1.6-2.0 mm). Eggs are oblong with rounded base and blunt apex, with a fibre-like basal pedestal or stalk $0.4-0.5 \mathrm{~mm}$ long. Yolk is light orange and occupies nearly $75 \%$ of the capsule. These eggs incubated in situ in turbid, almost lentic water at 28$30^{\circ} \mathrm{C}$. Similarly, egg clusters were found in early June 2000 at $14^{\circ} \mathrm{C}$ in the St. Clair River beneath limestone rocks and human artefacts. A cluster of approximately 300 eggs formed an oval patch (estimated area = $40 \mathrm{~cm}^{2}$ ) under a rock at a depth of $0.2-0.3 \mathrm{~m}$ in slow flowing water. Eggs $(\mathrm{n}=78)$ were $3.5 \mathrm{~mm}$ long and $2.0 \mathrm{~mm}$ wide (modal values, $3.7 \mathrm{~mm}$ and $2.1 \mathrm{~mm}$ ).

\section{Morphology}

Yolk, which is usually retained in the gut of fish 4.5 to $6.5 \mathrm{~mm}$ long, may persist to $11 \mathrm{~mm}$. At 5-8 $\mathrm{mm}$, minute teeth are present on the jaws. Origin of D1 is at the fourth myomere or fifth vertebra, whereas D2 originates at the seventh or eighth myomere (eleventh or twelfth vertebra). Scales first appear on midcaudal peduncle at approximately $8-9 \mathrm{~mm}$ and body scalation may be complete at $12-15 \mathrm{~mm}$.

The upper lip is protractile and jaw articulation is below the anterior margin of the pupil. The anterior tubular nostril protrudes, whilst the minute posterior nostril is flush. At about $13 \mathrm{~mm}$ the cranium is depressed, cheeks begin to enlarge, and sub-orbital canals and papillae are barely visible. At all sizes, the head is bluntly arrow-shaped in ventral profile (Figure 2). All spines and fin rays are formed, although principal rays are incomplete in the caudal fin. Pectoral fin rays are joined distally by membrane. A small genital papilla is first obvious at about $23 \mathrm{~mm}$.

Origin of D2 is on a vertical line with the anus and separated from D1 by a flap of tissue. Full complement of branched caudal rays is attained at about $20 \mathrm{~mm}$. At $22-25 \mathrm{~mm}$, the pectoral fins are slightly flared ventrally and depressed D2 and anal fins extend equally to mid-peduncle (Figure 3). Two short, stout spines support a transverse membrane on the pelvic fin, the whole forming a suctorial disc.

Fish $>30 \mathrm{~mm}$ have a moderately rounded snout and large protruding dorsolateral eyes above bulging cheeks. Sub-orbital papillae occur in transverse rows (Figure 4). The tip of the large fleshy upper lip is anterior to the lower, and the opening of the terminal mouth lies below the ventral margin of the eye. The centre of the pupil lies along a horizontal line with the origin of the pectoral fin. Gill openings are narrow. Ctenoid scales cover the body, whereas cycloid scales occupy the anterior nape and gill covers. In outline,

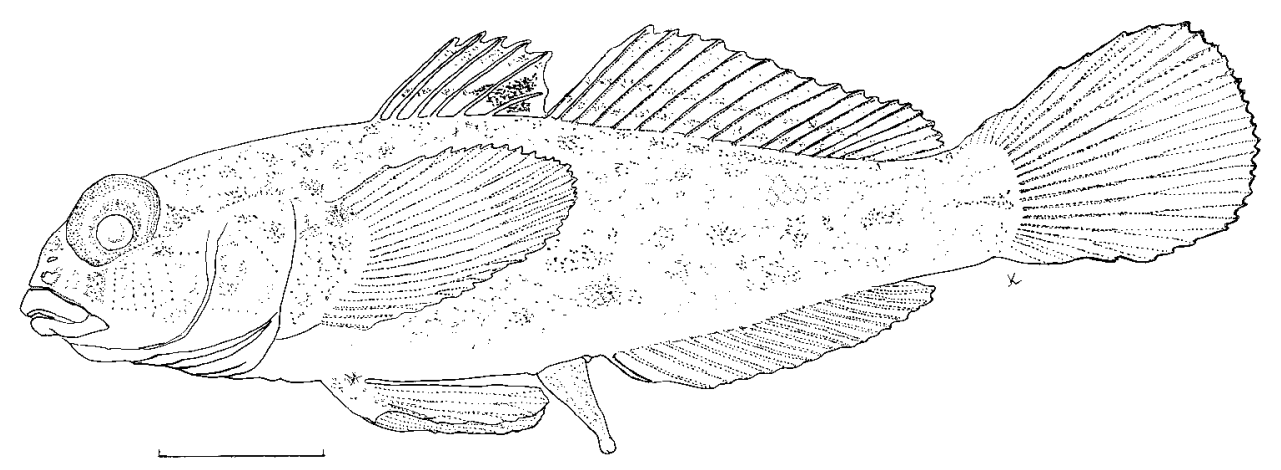

FiguRE 4. Lateral view of male Neogobius melanostomus at $38 \mathrm{~mm}$. Length bar $=5 \mathrm{~mm}$. 
TABLE 1. Morphometrics for age 0 Neogobius melanostomus collected in the St. Clair ecosystem, Ontario. Lengths are percentage (with range) of mean total length (TL) in each size class.

\begin{tabular}{|c|c|c|c|c|c|c|c|}
\hline $\begin{array}{l}\text { Size } \\
\text { class }\end{array}$ & $\begin{array}{l}5.0-8.9 \\
\mathrm{n}=20\end{array}$ & $\begin{array}{l}9.0-12.9 \\
\mathrm{n}=9\end{array}$ & $\begin{array}{l}13.0-16.9 \\
\mathrm{n}=2\end{array}$ & $\begin{array}{l}17.0-20.9 \\
\mathrm{n}=9\end{array}$ & $\begin{array}{l}21.0-24.9 \\
\mathrm{n}=21\end{array}$ & $\begin{array}{l}25.0-32.9 \\
\mathrm{n}=33\end{array}$ & $\begin{array}{l}33.0-39.9 \\
\mathrm{n}=23\end{array}$ \\
\hline Mean TL & $7.3 \pm 1.2$ & $10.4 \pm 1.2$ & $13.3 \pm 0.1$ & $18.5 \pm 0.9$ & $23.5 \pm 0.9$ & $28.7 \pm 2.1$ & $35.3 \pm 1.8$ \\
\hline \multirow[t]{2}{*}{ Standard } & 79.0 & 79.3 & 78.1 & 80.3 & 79.8 & 79.5 & 80.3 \\
\hline & $73-86$ & $78-83$ & $77-79$ & $79-83$ & $78-83$ & $77-81$ & $79-82$ \\
\hline \multirow[t]{2}{*}{ Preanal } & 45.8 & 43.8 & 41.5 & 44.0 & 44.7 & 44.0 & 43.4 \\
\hline & $43-52$ & $42-45$ & $41-42$ & $43-46$ & $41-48$ & $42-51$ & $39-46$ \\
\hline \multirow[t]{2}{*}{ Predorsal } & 33.0 & 31.2 & 30.6 & 30.1 & 29.7 & 29.2 & 28.2 \\
\hline & $30-42$ & $30-33$ & $30-32$ & $29-32$ & $28-32$ & $27-31$ & $24-29$ \\
\hline \multirow[t]{2}{*}{ Prepelvic } & 25.1 & 27.1 & 27.6 & 27.1 & 27.0 & 26.6 & 26.6 \\
\hline & $18-30$ & $24-31$ & $27-28$ & $26-28$ & $24-32$ & $25-29$ & $25-34$ \\
\hline \multirow[t]{2}{*}{ Body depth } & 17.8 & 16.8 & 15.5 & 17.5 & 16.9 & 17.6 & 17.7 \\
\hline & $14-21$ & $15-18$ & $14-17$ & $14-20$ & $15-19$ & $15-20$ & $16-19$ \\
\hline \multirow[t]{2}{*}{ Peduncle } & 7.5 & 8.0 & 8.3 & 9.0 & 8.9 & 8.9 & 8.8 \\
\hline & $6-9$ & $7-9$ & 0 & $9-10$ & $8-9$ & $9-10$ & $8-10$ \\
\hline \multirow[t]{2}{*}{ Head } & 26.2 & 26.3 & 27.6 & 25.5 & 25.3 & 24.8 & 24.0 \\
\hline & $21-30$ & $24-29$ & $27-28$ & $25-27$ & $24-27$ & $23-27$ & $23-26$ \\
\hline \multirow[t]{2}{*}{ Eye $^{a}$} & 30.6 & 31.1 & 27.6 & 33.0 & 32.4 & 32.2 & 30.3 \\
\hline & $25-37$ & $26-35$ & $27-28$ & $31-35$ & $28-35$ & $28-35$ & $26-35$ \\
\hline Volume $\left(\mathrm{mm}^{3}\right)$ & 12.3 & 30.1 & 55.7 & 189 & 357 & 732 & 1401 \\
\hline BDF & 5.6 & 6.1 & 6.5 & 5.8 & 6.0 & 5.7 & 5.6 \\
\hline $\mathrm{CDF}$ & 0.42 & 0.49 & 0.54 & 0.53 & 0.52 & 0.51 & 0.50 \\
\hline \multirow[t]{2}{*}{ Pectoral fin } & 18.6 & 19.7 & 21.5 & 23.6 & 24.0 & 23.5 & 23.6 \\
\hline & $10-22$ & $17-22$ & $21-22$ & $22-25$ & $22-25$ & $19-27$ & $21-26$ \\
\hline \multirow[t]{2}{*}{ Pelvic fin } & 15.5 & 17.2 & 19.3 & 21.3 & 19.9 & 20.1 & 19.8 \\
\hline & $9-21$ & $13-19$ & $18-20$ & $20-22$ & $18-21$ & $18-22$ & $17-23$ \\
\hline \multirow[t]{2}{*}{ Dorsal 1 base } & 7.0 & 7.8 & 6.5 & 8.8 & 8.5 & 9.0 & 9.2 \\
\hline & $5-11$ & $6-10$ & $6-7$ & $8-9$ & $7-12$ & $8-11$ & $7-11$ \\
\hline \multirow[t]{2}{*}{ Dorsal 2 base } & 24.3 & 23.5 & 23.4 & 25.2 & 24.7 & 25.9 & 25.5 \\
\hline & $19-30$ & $20-29$ & $23-24$ & $24-28$ & $20-29$ & $24-27$ & $24-27$ \\
\hline \multirow[t]{2}{*}{ Anal base } & 20.5 & 19.7 & 18.5 & 19.6 & 19.2 & 20.6 & 20.4 \\
\hline & $18-24$ & $16-23$ & $17-20$ & $17-22$ & $17-22$ & $17-23$ & $19-23$ \\
\hline
\end{tabular}

a $\%$ head length

D1 is slightly rounded, D2 slopes slightly, and the anal fin is uniform (Figure 4).

\section{Morphometry}

Relative changes in lengths are generally small as fish grow (Table 1). Head length (24-28\% TL) is 1.3 times its width and 1.4 times its depth. Snout length increased from $15 \% \mathrm{HL}$ at $7 \mathrm{~mm}$ to $20 \% \mathrm{HL}$ at $35 \mathrm{~mm}$. Interorbital width, variable among and within size classes, is $10-22 \%$ HL. Pectoral fin rays are $19-24 \%$ TL whereas D2 base is 23-26\% TL. Longest spines and base of D1 are about equal but less than the longest ray of D2. On fish $>35 \mathrm{~mm}$, the pectoral fin base is approximately $55 \%$ greatest body depth. Body depth and caudal depth factors are generally constant (Table 1).

\section{Meristics}

Respective modal counts for preanal, postanal, and total myomeres are 12 (range, 11-13), 19 (17-20), and 31 (29-32). Modal spine and fin ray complements are D1: VI, D2: I 15 (13-16), anal: I 13 (11-13), pectoral: 18 (16-19), pelvic(s): I 5 (conjoined), principal caudal:
13 (11-13). There are 33 modal (32-33) vertebrae and 49 (48-52) ctenoid scales in mid-lateral series.

\section{Pigmentation}

On free embryos, pigmentation consists of black eyes and several black spots on posterior spines of D1. However, on many specimens $<9 \mathrm{~mm}$, the characteristic black spot on D1 is absent. Speckled melanophores on snout and dorsum of head, a dark crescent on the occiput and a small patch on the cheek are typical at $10-12 \mathrm{~mm}$. Ventrally, an elongate stellate melanophore is situated mid-gut. About five faint dorsolateral clusters are expressed on the body. There is a small group of stellate melanophores on frontal and parietal areas, a ventral patch on the pectoral fin base and a subcutaneous series on the intestine. Melanophores develop at the base of each anal fin ray, and a narrow mid-ventral series prevails from anal fin base to caudal fin base (Figure 2). At $14 \mathrm{~mm}$, striation extends from maxilla to orbit and a black spot is pronounced between fifth and sixth spines on D1. Several faint mid-lateral blotches extend the length of the body. 


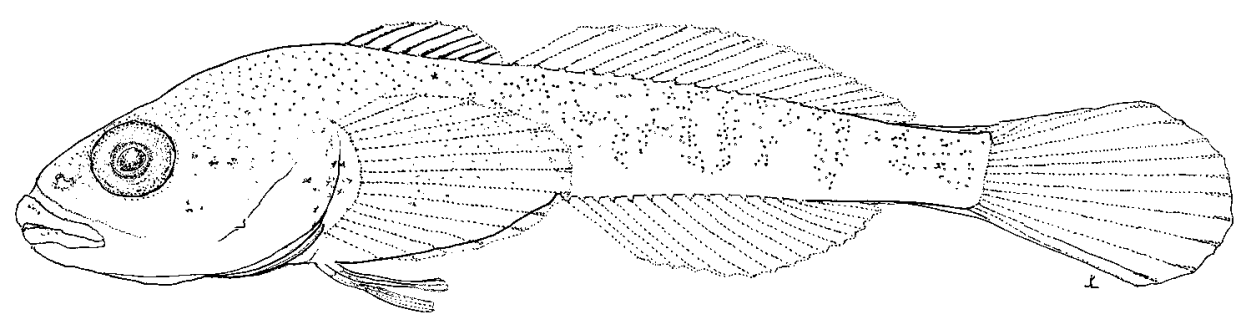

Figure 5. Cottus bairdi at $10.5 \mathrm{~mm}$. Length bar $=1 \mathrm{~mm}$.

At $22-25 \mathrm{~mm}$ a large brown patch is obvious on the dorsal peduncle of the pectoral fin. First four rays of D1 are lightly pigmented, and patches appear on the base of interradials. A faint stripe exists mid-fin on D1 (Figure 3). Posterior margins of body scales are darkly outlined and rays at the base of the caudal fin are lightly pigmented. A small basicaudal spot persists throughout development.

Fish $>30 \mathrm{~mm}$ have a small stripe on the preopercle, and about seven irregular patches of brown pigment on the side of the body, mainly below the mid-line. Otherwise, lips and dorsum of head are covered with small round spots, whilst the throat is essentially devoid of pigment. Pelvic and caudal fins are lightly spotted, whereas D2 has two pale longitudinal stripes. Pigmentation patterns are intensified over head, body, and fins (Figure 4). Overall colouration on individuals varies from dark brown to grey-brown.

\section{Description of age-0 Mottled Sculpin}

Mottled Sculpin larvae $(11.4 \pm 1.1 \mathrm{~mm} ; \mathrm{n}=5)$ have the following characters: preanal length $41 \%$ TL, head $25 \%$, eye $29 \%$ head length; head length and width equal; predorsal length $29 \%$ TL, prepelvic length 24\%. Branchiostegals 3,4. Except for pelvic fin separation, overall body characters are similar to gobies (Figure 5). Pigmentation features black eyes and approximately six lateral saddle marks on the body. Melanophores are absent on the ventral body surface and fins. Meristics for this, and superficially similar, species are given in Table 2 .

\section{Discussion}

The Round Goby is an eurythermal fish adapted to slightly brackish environments in the Caspian and Black seas (Miller 1986). In the Great Lakes basin it is ubiquitous in the littoral zone, including ecotones intolerable to many of our native fishes. Eggs incubate in almost static water in Duck Creek, a stream burdened with silt, and at times, blooms of bluegreen algae at high temperatures. Concurrently, eggs may develop in the St. Clair River in water of high quality and clarity at temperatures several degrees lower than in small turbid streams in the same catchment. The reproductive strategy includes parental guarding of eggs and free embryos. In the St. Clair aquatic ecosystem, age-0 Round Gobies appear to remain natal stream and shore habitats throughout their first year of growth. Solid objects, unlike sand and other unstable substrates, provide surfaces essential for attachment and refuge for small gobies in flowing water.

Reproduction is prolonged and extensive but varies geographically. In their native range, gobies migrate to spawning habitat at $9-26^{\circ} \mathrm{C}$ and reproduce from April-September in intervals of 3 or 4 weeks (Charlebois et al. 1997). Similar data for the Great Lakes are lacking, although MacInnis and Corkum (2000) suggest a possible spawning period from April to November in the upper Detroit River. In power plant cooling water discharges, the reproductive period may extend from winter to late summer or beyond, since the endocrine system is active all year (Charlebois et al. 1997) and water temperatures are constantly $>10^{\circ} \mathrm{C}$.

TABLE 2. Comparison of meristics of several Great Lakes age-0 fishes superficially similar in appearance.

\begin{tabular}{|c|c|c|c|c|c|c|c|c|}
\hline Species & $\begin{array}{l}\text { D1 } \\
\text { fin }\end{array}$ & $\begin{array}{l}\text { D2 } \\
\text { fin }\end{array}$ & $\begin{array}{l}\text { Pelvic } \\
\text { fin }\end{array}$ & $\begin{array}{l}\text { Pectoral } \\
\text { fin }\end{array}$ & $\begin{array}{c}\text { Anal } \\
\text { fin }\end{array}$ & $\begin{array}{c}\text { Preanal } \\
\text { myomeres }\end{array}$ & $\begin{array}{c}\text { Postanal } \\
\text { myomeres }\end{array}$ & References \\
\hline Etheostoma exile & VIII-X & $10-12$ & I, 5 & $12-14$ & II, 7-8 & & & Heufelder 1982 \\
\hline Etheostoma nigrum & VIII-XI & $10-14$ & I, 5 & $11-12$ & I, 7-10 & 15 & 21 & Heufelder 1982 \\
\hline Etheostoma caeruleum & $\mathrm{X}$ & 12 & 6 & 13 & II, 7 & $16-17$ & $18-19$ & Cooper 1979 \\
\hline \multirow[t]{2}{*}{ Cottus bairdi } & VII-IX & $16-19$ & I, 3-4 & $13-17$ & $13-14$ & $9-12$ & $19-21$ & Heufelder 1982 \\
\hline & VII-VIII & $15-17$ & I, 3-4 & $13-15$ & 13 & $9-10$ & $19-21$ & This study \\
\hline Cottus cognatus & VII-IX & $16-19$ & I, 3-4 & $12-16$ & $10-14$ & $9-12$ & 19 & Heufelder 1982 \\
\hline Proterorhinus marmoratus & VI-VII & $16-19$ & I, 5 & $14-15$ & $\mathrm{I}, 13$ & 11 & 20 & Leslie et al. 2002 \\
\hline Neogobius melanostomus & VI & $13-16$ & I, 5 & 18 & I, 13 & 12 & 19 & This study \\
\hline
\end{tabular}


In the study area, batches of about 200-300 eggs represent an absolute fecundity of 800-1200, assuming four spawning episodes. MacInnis and Corkum (2000) estimated an absolute fecundity of 252-1818 eggs based on three spawning episodes from late May to the end of July in the upper Detroit River. Miller (1986) reported fecundity of gobies $7-13 \mathrm{~cm}$ long as 328-5221 in the Black-Caspian-Azov seas, whilst Kuczyñski (1995) calculated 2700-3000 eggs in the Gulf of Gdansk. In general, fecundity is lower and eggs slightly smaller (3.7-3.9 mm long, 2.0-2.2 mm wide) than in the Black and Baltic seas, possibly because the spawning population is younger and fish are smaller (MacInnis and Corkum 2000).

Moskal'kova (1967) reared embryos that emerged from the egg at 5.5-5.7 $\mathrm{mm}$ and remained in the nest 4-9 days. Gobies do not have a true larval stage (Miller 1986) and hatch with most characteristics of juveniles. However, in the present study, smallest gobies (4.5$5.0 \mathrm{~mm}$ ) feature a large yolk sac and incomplete complement of fin rays. These fish may have extruded from eggs during the collection process and perhaps are not representative of free embryos. Otherwise, smallest specimens found in coarse gravel were clearly unguarded, free-living fish.

The Round Goby is a cryptic, benthic fish, devoid of air bladder and planktonic stage. As such, early developmental stages are found in and among firm structures. Gobies have smaller caudal and body depth factors than larvae capable of high thrust and acceleration, such as Anchovy (Eugraulidae), Alewife (Clupeidae) or percids (C. A. Timmins, unpublished, 2000). The Round Goby may not be a strong or fast swimmer, but its large head, robust body, and large pectoral fins enhance its manoeuvrability.

Age-0 Round and Tubenose gobies did not co-occur in any given habitat in the St. Clair ecosystem, although they partitioned habitat in a small area near the mouth of Duck Creek (Leslie and Timmins 1998). Usually, small age-0 Round and Tubenose gobies may be separated on the basis of head and body pigmentation, which is much lighter in the former. Whereas the Round Goby has a conspicuous black spot on the posterior spines of D1, the Tubenose Goby has an oblique stripe on anterior spines. Further, tubular nostrils that extend beyond the upper lip are peculiar to the Tubenose Goby. However, most mensural characters overlap for these gobies. Thus, small $(<6 \mathrm{~mm})$ unpigmented fish may not be separable.

Fishes with similar habitat requirements and morphology, such as cottids, darters, and gobies sometimes co-occur. Recently hatched Mottled Sculpins are precocious and appear similar to gobies (Figure 5). However, all fins are developed in recently hatched Round Gobies, whereas cottids (and darters) have a complete fin fold and separate pelvic fins, which are expressed some weeks post-hatch. In addition, preanal and total myomere counts of cottids and darters do not overlap with those of gobies. Fin spine and ray counts and pigmentation patterns also differ among these taxa.

The Round Goby has survival advantage over many competitors. It reproduces repeatedly from spring to autumn, the critical life stage is not determined by specific seasonal type or quantity of food, its embryos hatch with almost all external structures elaborated, the young are guarded in nests and it persists in natal habitats. Certainly, few native fishes of the Great Lakes basin are as morphologically and physiologically suited to thrive in comparable environmental conditions. Therefore, geographic range expansion and proliferation of the species seems likely in the Great Lakes Basin.

\section{Acknowledgments}

R. E. Dermott, Department of Fisheries and Oceans, Burlington, Ontario, kindly provided specimens of mottled sculpin. We thank two anonymous reviewers for comments that improved the manuscript.

\section{Documents Cited (marked $*$ in text)}

Skóra, K. E. 1997. Neogobius melanostomus. In Baltic Research Network on ecology of marine invasions and introductions. Edited by S. Olenin and D. Daunys. Internet: http:www.ku.lt/nemo/mainmeno.htm.

\section{Literature Cited}

Charlebois, P. M., J. E. Marsden, R. G. Goettel, R. K. Wolfe, D. J. Jude, and S. Rudnicka. 1997. The round goby, Neogobius melanostomus (Pallas) a review of European and North American literature. Illinois-Indiana Sea Grant Program and Illinois Natural History Survey. Special Publication Number 20.

Cooper, J. E. 1979. Description of eggs and larvae of Fantail (Etheostoma flabellum) and Rainbow (E. caeruleum) darters from Lake Erie tributaries. Transactions of American Fisheries Society 108: 446-456.

Crossman, E. J., E. Holm, R. Cholmondeley, and K. Tuininga. 1992. First record for Canada of the Rudd, Scardinius erythrophthalmus, and notes on the introduced Round Goby, Neogobius melanostomus. Canadian FieldNaturalist 106: 206-209.

Dubbs, D. O. L., and L. D. Corkum. 1996. Behavioural interactions between Round Gobies (Neogobius melanostomus) and Mottled Sculpin (Cottus bairdi). Journal of Great Lakes Research 22: 838-844.

Heufelder, G. R. 1982. Family Cottidae, sculpins. Identification of larval fishes of the Great Lakes basin with emphasis on the Lake Michigan drainage. Pages 1-774 in Great Lakes Fisheries Commission Special Publication 8283. Edited by N. A. Auer. Ann Arbor, Michigan.

Jude, D. J., R. H. Reider, and G. R. Smith. 1992. Establishment of Gobiidae in the Great Lakes Basin. Canadian Journal of Fisheries and Aquatic Sciences 49: 416-421.

Kalinina, E. M. 1976. [Abstract] Reproduction and early development of gobies from the Azov and Black seas. Kiev. Nauk Dumka, Russia.

Koblickaja, A. F. 1981. [Abstract]. Opredielitiel molodii priesnowodnyh rby Moskva. Legkaja i pischevaja promyslennost 208. [cited in Charlebois et al. 1997]. 
Kuczyñski, J. 1995. Babka kràgùa Neogobius melanostumus (Pallas 1811) - emigrant z Basenu Pontokaspijskiego w zatoce Gdañskiej. Bulletin Sea Fisheries Institute, Gdynia 2(135): 68-71.

Leslie, J. K., and C. A. Timmins. 1998. Fish reproduction and distribution in a small tributary of Lake St. Clair. Canadian Technical Report of Fisheries and Aquatic Sciences 2253.

Leslie, J. K., C. A. Timmins, and R. G. Bonnell. 2002. Postembryonic development of the tubenose goby Proterorhinus marmoratus Pallas (Gobiidae) in Lake St. Clair and the St. Clair River. Archivum für Hydrobiologie 154: 341-352.

MacInnis, A. J., and L. D. Corkum. 2000. Fecundity and reproductive season of the Round Goby Neogobius melanostomus in the upper Detroit River. Transaction of American Fisheries Society 129: 136-144.

Miller, P. J. 1986. Gobiidae. Pages 1019-1095 in Fishes of the North-eastern Mediterranean. Edited by P. J. P. White- head, M.-L. Bauchot, J.-C. Hureau, J. Nielsen, E. Tortonese. Volume 3: UNESCO, Paris.

Moskal'kova, K. I. 1967. Morpho-ecological specifics of development of the Round Goby, Neogobius melanostomus (Pallas). Pages 48-75 in Morphological and ecological analysis of fish development. Nauka, Moskow. [In Russian].

Nelson, J. S. 1984. Fishes of the World. Second edition. John Wiley and Sons. Toronto. 523 pages.

Trautman, M. B. 1981. The fishes of Ohio. Ohio State University Press. Columbus, Ohio. 782 pages.

Webb, P. W., and Weihs, D. 1986. Functional locomotor morphology of early life history stages of fish. Transactions of American Fisheries Society 115: 115-127.

Received 17 February 2003

Accepted 15 November 2004 